\title{
Morbidity, Mortality and Major Bile Duct Injury in 2296 Patients Undergoing Laparoscopic Cholecystectomy - Review of Literature
}

\author{
Shing-Moo Huang, 1,2,6*, Nan-Lan Huang ${ }^{4}$, Shueh-Ding Huang ${ }^{5}$ and Huichin Pan ${ }^{2,3,6}$ \\ ${ }^{1}$ Institute and School of Medicine, Chung Shan Medical University, Taiwan \\ ${ }^{2}$ Division of General Surgery, Chung Shan Medical University Hospital, Taiwan \\ ${ }^{3}$ Institute of Pharmacology, College of Medicine, National Taiwan University, Taiwan \\ ${ }^{4}$ Department of Applied Mathematics, National Chengchi University, Taiwan \\ ${ }^{5}$ Department and Institute of Biomedical Sciences, Chung Shan Medical University, Taiwan \\ ${ }^{6}$ Department of Medical Research, Chung Shan Medical University Hospital, Taiwan
}

Submission: March9, 2017; Published: July 21, 2017

*Corresponding author: Shing-Moo Huang, 3-2th floor, No. 76, Ren-Yee street, South District, Taichung city, Taiwan, Tel: 886-4-22850527;

Fax: 886-4-24062026; Email: shingmooeel@yahoo.com.tw

\begin{abstract}
Aims: The aims were at the safety of laparoscopic cholecystectomy in the treatment of gallbladder diseases in a series of 2296 patients. Also reports in literature were reviewed.

Materials: Between January 1, 1999 and July 31, 2013, 2296 patients with gallbladder disease undergoing laparoscopic cholecystectomy were recruited. Demographics such as age, gender, indications, associated diseases, conversions, stone types, perioperative morbidity, major bile duct injury and mortality were recorded.

Results: There were 61 conversions. The conversion rate was $2.7 \%$. Indications for laparoscopic cholecystectomy include symptomatic gallstones $(2,135,93 \%)$, gallbladder polyps $(115,5 \%)$ and others $(46,2 \%)$. We found our morbidity rate was $2.18 \%(50)$, mortality rate $0.04 \%$ (1) and major bile duct injury rate 0.08 (2).

Conclusion: In this observational study, it was found the morbidity, mortality and major bile duct injury rates were lower than those of laparoscopic cholecystectomy reported. The mortality and major bile duct injury rates were also lower than those of open cholecystectomy reported. However morbidity rate of our series was higher than that of open cholecystectomy.
\end{abstract}

Keywords: Laparoscopic cholecystectomy; Morbidity; Mortality; Safety: major bile duct injury

\section{Introduction}

Phillippe Mouret performed the first videoscopic laparoscopic cholecystectomy on a human patient in 1987 [1]. Since then, this new advancement in the history of general surgery has gained wide acceptance and entered daily practice for general surgeons throughout the world [2-8]. With a few exceptional randomized controlled studies [6], most efficacy and safety studies for laparoscopic cholecystectomy were observational and retrospective case controlled studies [9]. Therefore, this study aims at the safety of laparoscopic cholecystectomy as compared among those of reports in the literature and the author's personal series. Safety of open cholecystectomy was also compared.

\section{Materials and Methods}

\section{Patients}

This is an observational study. Between January 1, 1999 and July 31, 2013, 2296 patients with gallbladder disease were recruited and underwent laparoscopic cholecystectomy by the author at Veterans General Hospital-Taipei and Chung Shan Medical University.

\section{Results}

\section{Demographics}

The $\mathrm{M} / \mathrm{F}$ ratio was 1:1.03 for symptomatic gallstones, 1.661:1 for chronic cholecystitis but $1.25: 1$ for acute and sub-acute 
cholecystitis. In acute cholecystitis patients, male predominant was found whereas female predominant was found in chronic cholecystitis patients $(\mathrm{P}<0.0001)$. The average age for patients with symptomatic gallstones, chronic cholecystitis and acute cholecystitis are $54 \pm 15,53 \pm 15$ and $57 \pm 17$ years old.

\section{Indications for laparoscopic cholecystectomy}

These include symptomatic gallstones (2,135, 93\%), gallbladder polyps $(115,5 \%)$ and others $(46,2 \%)$.

\section{Morbidity and mortality}

There are 50 operative complications (50/2,296, 2.18\%), i.e., common bile duct injury $(4,0.17 \%)$, right hepatic duct injury $(1,0.04 \%)$, bile leakage $(4,0.17 \%)$, hypoxic encephalopathy (1, 0.04\%), spontaneous pneumothorax (1, 0.04\%), right perihepatic abscess $(3,0.13 \%)$, perioperative hemorrhage $(3$, $0.13 \%)$, intestinal perforation $(1,0.04 \%)$, wound infection $(29$, $1.26 \%)$ and urinary tract infection $(3,0.13 \%)$ (Table 1$)$.

The patient complicated with hypoxic encephalopathy was a 76-year-old male diagnosed with gallstone with acute cholecystitis. Preoperative electrocardiogram did not reveal any cardiac arrhythmia. The operative procedure was uneventful except that it was a relatively long procedure. The operation time was 121 minutes. An episode of bradycardia developed which was followed by a cardiac arrest.

After resuscitation, the patient's heartbeat and respiration returned. However, the consciousness did not return. Glasgow coma scale was 4 (E1V1M2). The patient did not recover from the hypoxic encephalopathy and finally succumbed to consequent pneumonia. This is the only mortality in this series. The patient complicated with spontaneous pneumothorax was a 65-year-old male associated with chronic obstructive pulmonary disease. Intra-operatively, the anesthesiologist noted a drop of oxygen saturation from $98 \%$ to $90 \%$ at $50 \%$ alveolar oxygen concentration. Auscultation revealed decreased breathing sound over right lung field. Emergent insertion of a pigtail drain into right pleural cavity revealed a jet of air emitting out. The operation was completed smoothly. The pigtail was removed 3 days postoperatively and was discharged on 4 th postoperative day.

There were 32 surgical infections associated with laparoscopic cholecystectomy in this series (1.39\%), including $3(0.13 \%)$ right peri-hepatic abscesses and 29 (1.26\%) wound abscesses. The former tended to suffer from spiking fever and right upper abdominal pain 2 weeks after laparoscopic cholecystectomy. Ultrasonography revealed sonolucent fluid collections around peri-hepatic spaces were detected. Ultrasound-guided insertion of pigtail drains and intravenous antibiotics were all that were needed to resolve these conditions. The patients were discharged around 7 days later. The latter were managed by incisional drainage and open wound dressings successfully.

There was one patient who had undergone previous abdominal surgery. This 56-year-old male patient underwent laparoscopic cholecystectomy for gallbladder stone with open laparoscopic technique. A severe small intestinal loop adhesion directly under the umbilicus was found. The procedure was completely. However, on the 3rd postoperative day, profuse yellowish small intestinal contents flew out from the infraumbilicus trocar wound. The patient underwent immediate reoperation and a $6 \mathrm{~cm}$ transverse extension of the infra-umbilicus wound was performed. A small $0.3 \mathrm{~cm}$ perforation hole was found at a mid-jejunum loop located immediately below the umbilicus. Primary repair with peritoneal cavity lavage was performed and the wound was closed. The postoperative course was uneventful and the patient was discharged 7 days later.

Three patients suffered from urinary tract infections. They received Foley catheter insertion after general anesthesia because longer operation was expected. Among them, two were from the contracted gallbladder group. Antibiotics and sulfa drugs were all that were needed to resolve the condition (Table 1).

Table 1: Major complications in a series of consecutive 2,296 laparoscopic Cholecystectomies.

\begin{tabular}{|c|c|c|}
\hline Complications & No. & $\%$ \\
\hline Common bile duct injury & 4 & 0.17 \\
\hline Right hepatic duct injury & 1 & 0.04 \\
\hline Bile leakage & 4 & 0.13 \\
\hline Hypoxic encephalopathy & 1 & 0.04 \\
\hline Spontaneous pneumothorax & 1 & 0.04 \\
\hline Right perihepatic abscess & 3 & 0.13 \\
\hline Perioperative hemorrhage & 3 & 0.13 \\
\hline Intestinal perforation & 1 & 0.04 \\
\hline Wound infection & 29 & 1.26 \\
\hline Urinary tract infection & 3 & 0.13 \\
\hline Total & 50 & 2.18 \\
\hline
\end{tabular}

\section{Biliary complication}

There were 2 patients with major bile duct injury (patients 1 and 8 in Table 2), 3 patients with minor bile duct injury (patients 5,6 and 7) and 4 patients' with delayed bile leakage (patients 2 , 3, 4 and 9, Table 2).

Major bile duct injury patients required more sophisticated repairing procedures, such as hepato-jejunostomy or choledochojejunostomy (patient 1 and patient 8). Their prognosis needs longer periods of follow-up to make sure they are not inflicted with recurrent cholangitis like biliary cripples, as patients 1 and 8 were devoid of these episodes for 6 - 7 years. 
Minor bile duct injury patients required only simpler managements, such as, primary repair with T-tube splinting or simple T-tube insertion would suffice in patients 5, 6 and 7. The prognosis was usually good.
Patients with delayed bile leakage also required only simple management, such as, T-tube insertion, which solved the problem in patients $2,3,4$ and 9 . Their prognosis was uniformly good within 7 days (Table 2).

Table 2: Bile duct injury and bile leakage in laparoscopic cholecystectomy (LC) in a series of 2,296 patients.

\begin{tabular}{|c|c|c|c|c|c|c|c|c|c|c|}
\hline \multirow{2}{*}{ No. } & \multirow{2}{*}{ Sex } & \multirow{2}{*}{ Age } & \multicolumn{2}{|c|}{ Case no. of LC } & \multirow{2}{*}{ Complication } & \multirow{2}{*}{ Mechanism } & \multirow{2}{*}{ PODE } & \multirow{2}{*}{ Risk factor } & \multirow{2}{*}{ Management } & \multirow{2}{*}{ Outcome } \\
\hline & & & Surg.'s & Hos.'s & & & & & & \\
\hline 1 & $\mathrm{~F}$ & 70 & 5 & 5 & CBDA injury & $\begin{array}{l}\text { Short cystic duct, } \\
\text { axial traction } \\
\text { failure of operative } \\
\text { cholangiogram }\end{array}$ & 0 & $\begin{array}{l}\text { Inexperience of } \\
\text { surgeon }\end{array}$ & $\begin{array}{l}\text { Primary } \\
\text { repair With } \\
\text { T-tube } \\
\text { splinting } \\
\text { Choledocho- } \\
\text { jejunostomy }\end{array}$ & $\begin{array}{c}\text { CBD } \\
\text { stricture } 18 \\
\text { months later } \\
\text { Well } 6 \text { years } \\
\quad \text { later }\end{array}$ \\
\hline 2 & M & 65 & 39 & 39 & $\begin{array}{l}\text { Delayed } \\
\text { bileleakage }\end{array}$ & $\begin{array}{c}\text { Delayed } \\
\text { electrocautery } \\
\text { Injuryof cystic-CBD } \\
\text { junction }\end{array}$ & 12 & Smoky abdomen & $\begin{array}{l}\text { Laparotomy } \\
\text { + T-tube } \\
\text { insertion }\end{array}$ & $\begin{array}{l}\text { Well, remove } \\
\text { T-tube } 7 \\
\text { days later }\end{array}$ \\
\hline 3 & M & 48 & 89 & 100 & $\begin{array}{l}\text { Delayed } \\
\text { bileleakage }\end{array}$ & $\begin{array}{l}\text { Electrocautery } \\
\text { injuryor pigtail } \\
\text { erosion }\end{array}$ & 13 & Smoky abdomen & $\begin{array}{l}\text { Laparotomy } \\
\text { + T-tube } \\
\text { insertion } \\
\end{array}$ & $\begin{array}{c}\text { Well, remove } \\
\text { T-tube } 7 \\
\text { days later } \\
\end{array}$ \\
\hline 4 & M & 56 & 110 & 160 & $\begin{array}{l}\text { Delayed } \\
\text { bileleakage }\end{array}$ & $\begin{array}{c}\text { Delayed } \\
\text { electrocautery } \\
\text { Injuryof cystic-CBD } \\
\text { junction }\end{array}$ & 14 & Smoky abdomen & $\begin{array}{l}\text { Laparotomy } \\
\text { + T-tube } \\
\text { insertion }\end{array}$ & $\begin{array}{l}\text { Well, remove } \\
\text { T-tube } 12 \\
\text { days later }\end{array}$ \\
\hline 5 & M & 54 & 201 & 313 & RHDB injury & Mistake RHD for CDD & 0 & $\begin{array}{l}\text { obscured } \\
\text { anatomy }\end{array}$ & $\begin{array}{l}\text { long arm } \\
\text { T-tube stent }\end{array}$ & $\begin{array}{l}\text { Remove } \\
\text { T-tube } 6 \\
\text { months }\end{array}$ \\
\hline 6 & M & 56 & 301 & 412 & CBD injury & Mistake CBD for CD & 0 & $\begin{array}{c}\text { Contracted } \\
\text { gallbladder } \\
\text { fibrosed Calot's } \\
\text { triangle } \\
\end{array}$ & $\begin{array}{l}\text { long arm } \\
\text { T-tube stent }\end{array}$ & $\begin{array}{l}\text { Well } 6 \\
\text { months }\end{array}$ \\
\hline 7 & M & 56 & 330 & 475 & CHDC injury & Mistake CHD for CD & 0 & $\begin{array}{l}\text { Contracted } \\
\text { gallbladder } \\
\text { fibrosed Calot's } \\
\text { triangle, obscure } \\
\text { anatomy }\end{array}$ & $\begin{array}{l}\text { long arm } \\
\text { T-tube stent }\end{array}$ & $\begin{array}{l}\text { Well } 2 \\
\text { months }\end{array}$ \\
\hline 8 & $\mathrm{~F}$ & 38 & 1451 & 3,765 & CBD injury & Mistake CBD for CD & 5 & $\begin{array}{l}\text { Obesity fatty } \\
\text { liver an anomaly } \\
\text { of posterior } \\
\text { branch of cystic } \\
\text { artery }\end{array}$ & $\begin{array}{c}\text { Laparotomy } \\
\text { + hepatico- } \\
\text { jejunostomy+ } \\
\text { Roux-en-y } \\
\text { jejuno- } \\
\text { jejunostomy }\end{array}$ & $\begin{array}{l}\text { Paralytic } \\
\text { ileus W'dF } \\
\text { infection } \\
\text { Well 7years }\end{array}$ \\
\hline 9 & M & 67 & 1502 & 4,175 & $\begin{array}{l}\text { Delayed } \\
\text { bileleakage }\end{array}$ & $\begin{array}{l}\text { Delayed cystic stump } \\
\text { clip loosening }\end{array}$ & 7 & $\begin{array}{l}\text { Short cystic } \\
\text { stump }\end{array}$ & $\begin{array}{l}\text { ENBDG + CT - } \\
\text { guided pigtail } \\
\text { drainage }\end{array}$ & $\begin{array}{c}\text { Remove } \\
\text { pigtail } \\
\text { (ENBD) 4(7) } \\
\text { days Well } 7 \\
\text { years } \\
\end{array}$ \\
\hline
\end{tabular}

${ }^{A} \mathrm{CBD}$ : common bile duct, ${ }^{\mathrm{B} R H D}$ : right hepatic duct, ${ }^{\mathrm{C}} \mathrm{CHD}$ : common hepatic duct, ${ }^{\mathrm{D}} \mathrm{CD}$ : cystic duct, E: POD: post-operative day, ${ }^{\mathrm{F} W}$ 'd: wound, GENBD: endoscopic naso-biliary drainage.

\section{Discussion}

Undoubtedly, laparoscopic cholecystectomy is the greatest arena for laparoscopic surgery. From literature, the overall morbidity and mortality of laparoscopic cholecystectomy are no different from those of open cholecystectomy. From Tables $3 \& 4$, the average morbidity of laparoscopic cholecystectomy is $5.2 \%$ (range $1.2 \%-23.3 \%$ ) whereas that of open cholecystectomy is $0.13 \%$ (range $0.76 \%-35.2 \%$ ). The average mortality of laparoscopic cholecystectomy is $0.46 \%$ (range $0 \%-0.8 \%$ ). The average mortality of open cholecystectomy is $0.27 \%$ (range $0.0 \%-0.8 \%$ ). There is a pattern of the incidence of major bile duct injury requiring biliary reconstruction corresponding to the case number of the surgeon. Major bile duct injury is high or none in the surgeon's learning curve period (the first 100 cases to less than 500 cases, Table 3), also as in case 1 of Table 2 in this series. Not with standing the experienced surgeon has past the learning curve period, the incidence of major bile duct 
injury did not fall $[10,11]$. It looks as if when surgeon passed his first 500 and less than 1,000 cases, he begins handling more complicated cases and major bile duct injury incidence tends to re-appear, i.e., $0.79-1.4 \%$, as case 9 of Table 2 in this series. With further experiences gained with increasing case number beyond 1,000 the surgeon's laparoscopic cholecystectomy-associated incidence begins to descend and level off, i.e., $0.1-0.6 \%[8,12-$ 13].

In this observational study of 2,296 patients undergoing laparoscopic cholecystectomy, we found our morbidity rate was $2.18 \%(50 / 2,296)$, mortality rate $0.04 \%(1 / 2,296)$ and major bile duct injury rate $0.08(2 / 2,296)$, lower than the average of those of laparoscopic cholecystectomy in the literature: $5.2 \%$ $(8,072 / 155,622$, Table 3), 0.46\% (27,635/6,040,632, Table 3) and $0.22 \%(16,382 / 7,559,461$, Table 3$)$. In mortality rate and major bile duct injury rate, we found our series are lower than the average of open cholecystectomy in the literature: $0.04 \%$ $(1 / 2,296)$ and $0.08(2 / 2,296)$ vs. $0.27 \%(158 / 59,332$, Table 4$)$ and $0.55 \%(30 / 5,445$, Table 4$)$. However, in morbidity rate, our series are higher than the average of open cholecystectomy in the literature: $2.18 \%(50 / 2,296)$ vs. $0.13 \%(7,608 / 59,332$, Table 4).

In turn, for morbidity rate, the order of lowest rate was: the average of open cholecystectomy in the literature $0.13 \%$ $(7,608 / 59,332$, Table 4$)$, our series $2.18 \%(50 / 2,296)$ and then laparoscopic cholecystectomy in the literature $5.2 \%$ $(8,072 / 155,622$, Table 3$)$. For mortality rate, the order of lowest rate was: our series $0.04 \%(1 / 2,296)$, the average of open cholecystectomy in the literature $0.27 \%(158 / 59,332$, Table 4) and then the average of laparoscopic cholecystectomy in the literature $0.46 \%(27,635 / 6,040,632$, Table 3$)$. For major bile duct injury rate, the order of lowest rate was: our series $0.08(2 / 2,296)$, the average of laparoscopic cholecystectomy in the literature $0.22 \%(16,382 / 7,559,461$, Table 3$)$ and then the average of open cholecystectomy in the literature of open cholecystectomy $0.55 \%(30 / 5,445$, Table 4$)$.

Table 3: Overall incidences of morbidity, mortality and bile duct injury during laparoscopic cholecystectomy.

\begin{tabular}{|c|c|c|c|c|c|c|c|c|}
\hline Author & Year & $\begin{array}{l}\text { No. of } \\
\text { Patient }\end{array}$ & $\begin{array}{c}\text { Overall } \\
\text { Morbidity No. } \\
(\%)\end{array}$ & $\begin{array}{c}\text { Overall Morbidity } \\
\text { No. (\%) }\end{array}$ & $\begin{array}{l}\text { Orma No. } \\
\quad(\%)\end{array}$ & $\begin{array}{l}\text { Normb }^{\text {b No. }} \\
\text { (\%) }\end{array}$ & Bdi $^{\mathrm{c}}$ No. (\%) & Reference \\
\hline Spangenberger & 1990 & 100 & $3(3)$ & $0(0)$ & $0(0)$ & $0(0)$ & $0(0)$ & {$[14]$} \\
\hline Smith & 1992 & 486 & $41(8.4)$ & $1(0.2)$ & - & - & - & [15] \\
\hline Deziel & 1993 & 77,604 & $931(1.2)$ & $33(0.04)$ & $18(0.02)$ & $15(0.02)$ & $466(0.6)$ & [12] \\
\hline Calvete & 2000 & 874 & - & - & - & - & $11(1.4)$ & [16] \\
\hline Krähenbühl & 2001 & 12,111 & - & - & - & - & $36(0.3)$ & [13] \\
\hline Flum & 2003 & $1,570,361$ & - & - & - & - & $7911(0.5)$ & [17] \\
\hline Dolan & 2005 & $2,841,186$ & - & $12,785(0.45)$ & - & - & $4,061(0.15)$ & [18] \\
\hline Halilovic & 2011 & 293 & $5(1.7)$ & $0(0)$ & $0(0)$ & $0(0)$ & $0(0)$ & [19] \\
\hline Huang $^{\mathrm{d}}$ & 2011 & 1468 & 1468 & $1(0.07)$ & $0(0)$ & $1(0.07)$ & $2(0.14)^{e}$ & [8] \\
\hline Grbas & 2013 & 10,317 & $2,402(23.3)$ & $0(0)$ & $0(0)$ & $0(0)$ & $25(0.2)$ & [20] \\
\hline Sajid & 2014 & 504 & $16(3.17)$ & $2(0.39)$ & - & - & $4(0.79)$ & [10] \\
\hline Fry & 2015 & 64,021 & $4,624(7.2)$ & $509(0.8)$ & - & - & - & {$[21]$} \\
\hline Worth & 2015 & $3,043,814$ & - & $14,304(0.47)$ & - & - & $3,866(0.1) \mathrm{f}$ & [11] \\
\hline \multicolumn{2}{|c|}{ Pooled Data } & $\begin{array}{l}\text { No. of } \\
\text { Patient }\end{array}$ & Morbidity (\%) & Mortality (\%) & BDI (\%) & Reference & \multicolumn{2}{|c|}{ Reference } \\
\hline & & 155622 & $8072(5.2)$ & - & - & {$[8,10,12]$} & \multicolumn{2}{|c|}{ [14-15,19-21] } \\
\hline & & 6040622 & - & $27635(0.46)$ & - & {$[8,10-12]$} & \multicolumn{2}{|c|}{ [14-15,18-21] } \\
\hline & & 7559461 & - & - & $\begin{array}{l}16382 \\
(0.22)\end{array}$ & {$[8,10-14]$} & \multicolumn{2}{|c|}{ [16-21] } \\
\hline
\end{tabular}

a operation related mortality ${ }^{b}$ non-operation related mortality ${ }^{c}$ major bile duct injuryd author's (SMH) personal series, e 3 minor bile duct injuries in which no biliary reconstruction was required were not included, fBile duct reconstructions were associated with $4.4 \%$ mortality. 
Table 4: Overall incidence of morbidity, mortality and bile duct injury during open cholecystectomy.

\begin{tabular}{|c|c|c|c|c|c|c|c|c|}
\hline Author & Year & $\begin{array}{c}\text { No. of } \\
\text { Patient }\end{array}$ & $\begin{array}{l}\text { Overall } \\
\text { Morbidity } \\
\text { No. (\%) }\end{array}$ & $\begin{array}{c}\text { Overall } \\
\text { Morbidity } \\
\text { No. (\%) }\end{array}$ & $\begin{array}{c}\text { Orm }^{\text {a }} \text { No. } \\
\text { (\%) }\end{array}$ & $\begin{array}{c}\text { Normb }^{b} \text { No. } \\
\text { (\%) }\end{array}$ & Bdic No. (\%) & Reference \\
\hline Cox & 1992 & 457 & $161(35.2)$ & $0(0)$ & $0(0)$ & $0(0)$ & - & [22] \\
\hline Smith & 1992 & 486 & $39(8)$ & $0(0)$ & - & - & - & [15] \\
\hline Roslyn & 1993 & 42,473 & 6,244 (14.7) & $71(0.17)$ & - & - & - & [23] \\
\hline Girard & 1993 & 10,471 & $614(6.1)$ & $47(0.4)$ & - & - & - & [24] \\
\hline Cagir & 1994 & 262 & $2(0.76)$ & $0(0)$ & $0(0)$ & $0(0)$ & $1(0.38)$ & [25] \\
\hline Moreax & 2001 & 5,000 & $525(10.5)$ & $40(0.8)$ & $35(0.7)$ & $5(0.1)$ & $29(0.6)$ & [26] \\
\hline Halilovic & 2011 & 183 & $23(12.5)$ & $0(0)$ & $0(0)$ & $0(0)$ & $0(0)$ & [19] \\
\hline \multirow[t]{4}{*}{ Pooled Data } & & $\begin{array}{c}\text { No. of } \\
\text { Patient }\end{array}$ & $\begin{array}{c}\text { Morbidity } \\
\text { (\%) }\end{array}$ & $\begin{array}{c}\text { Mortality } \\
(\%)\end{array}$ & BDI (\%) & Reference & Reference & \\
\hline & & 59332 & $7608(0.13)$ & - & - & {$[15,19]$} & {$[22-26]$} & \\
\hline & & 59332 & - & $158(0.27)$ & - & {$[15,19]$} & [22-26] & \\
\hline & & 5445 & - & - & $30(0.55)$ & [19] & [25-26] & \\
\hline
\end{tabular}

${ }^{a}$ operation related mortality ${ }^{b}$ non-operation related mortality ${ }^{~}$ major bile duct injury.

\section{Conclusion}

In conclusion, an observational study was conducted on 2296 patients with gallbladder disease undergoing laparoscopic cholecystectomy. It was found our morbidity, mortality and major bile duct injury rates were lower than those of laparoscopic cholecystectomy reported in the literature. The mortality and major bile duct injury rates were also lower than those of open cholecystectomy reported in the literature. However morbidity rate of our series was higher than that of open cholecystectomy.

\section{Authors Contribution}

A. Study concept and design: Huang SM, Huang NL, Huang SD and Pan H. Acquisition of data: Huang SM and Huang SD. Analysis and interpretation of data: Huang SM, Huang SD, Huang $\mathrm{NL}$, and Pan $\mathrm{H}$.

B. Drafting of the manuscript: Huang SM, Huang NL, Huang SD, and Pan H.

C. Critical revision of the manuscript for important intellectual content: Huang SM, Pan H and Huang NL.

D. Statistical analysis: Huang SD. Obtained funding: Huang SM, Pan H. Administrative, technical and material support: Pan H. Study supervision: Pan H.

E. Funding: This study was supported partially by grants from Chung Shan Medical University with grants No. CSMUTTM-097-001 and CSMU-TTM-098-002.

\section{References}

1. Polychronidis A, Laftsidis P, Bounovas A, Simopoulos C (2008) Twenty years of laparoscopic cholecystectomy: Philippe Mouret--March 17, 1987. JSLS 12(1): 109-111.
2. Dubois F, Icard P, Berthelot G, Levard H (1990) Coelioscopic cholecystectomy: preliminary report of 36 cases. Ann Surg 211(1): 6062.

3. Reddick EJ (1990) Laparoscopic laser cholecystectomy: the first 450 50 cases. Lasers Surg Med 10 (suppl 2): 21.

4. Cuschieri A, Berci G, McSherry CK (1990) Laparoscopic cholecystectomy. Am J Surg 159(3): 273.

5. Zucker KA, Bailey RW, Gadacz TR, Imbembo AL (1991) Laparoscopic guided cholecystectomy. Am J Surg 161(1):36-42.

6. Huang SM, Wu CW, Lui WY, P'eng FK (1996) A prospective randomized study of laparoscopic versus open cholecystectomy in aged patient with cholecystolithiasis. South Afr J Surg 34(4): 177-180.

7. Huang SM, Wu CW, Hong HT, Ming L, King KL, et al. (1993) Bile duct injury and bile leakage in laparoscopic cholecystectomy. Br J Surg 80(12): 1590-1592.

8. Huang SM, Hsiao KM, Pan H, Yao CC, Lai TJ, et al. (2011) Overcoming the difficulties in laparoscopic management of contracted gallbladders with gallstones: possible role of fundus-down approach. Surg Endosc 25(1): 284-291.

9. Neugebauer E, Troidl H, Spangenberger W, Dietrich, Lefering R (1991) Conventional versus laparoscopic cholecystectomy and the randomized controlled trial. Br J Surg 78(2): 150-154.

10. Sajid MT, Hussain SM, Bashir RA, Mustafa QA, Ahmed M, et al. (2014) Laparoscopic cholecystectomy: experience at a tertiary level hospital. J Ayub Med Coll Abbottabad 26(2): 225-229.

11. Worth PJ, Kaur T, Diggs BS, Sheppard BC, Hunter JG, et al. (2015) Major bile duct injury requiring operative reconstruction after laparoscopic cholecystectomy: a follow-on study. Surg Endosc 30(5): 1839-1846.

12. Deziel D, Millikan K, Economou S, Doolas A, Ko ST, et al. (1993) Complications of laparoscopic cholecystectomy: a national survey of 4,292 hospitals and an analysis of 77,604 cases. Am J Surg 165(1): 9-14.

13. Krähenbühl L, Sclabas G, Wente M, Schäfer M, Schlumpf R, et al. (2001) Incidence, risk factors, and prevention of biliary tract injuries during 
laparoscopic cholecystectomy in Switzerland. World J Surg 25(10): 1325-1330.

14. Spangenberger W, Klein J, Troidl H (1990) Laparoscopic cholecystectomy-initial experiences and results. Langenbecks Arch Chir Suppl II Verh Dtsch Ges Chir 1990: 1361-1368.

15. Smith JF, Boysen D, Tschirhart J, Williams T, Vasilenko P (1992) Comparison of laparoscopic cholecystectomy versus elective open cholecystectomy. J Laparoendosc Surg 2(6): 311-317.

16. Calvete J, Sabater L, Camps B, Verdu A, Gomez-Portilla A, et al. (2000) Bile duct injury during laparoscopic cholecystectomy. Myth or reality of the learning curve? Surg Endosc 14(7): 608-611.

17. Flum DR, Cheadle A, Prela C, Dellinger EP, Chan L (2003) Bile duct injury during cholecystectomy and survival in medicare beneficiaries. JAMA 290(16): 2168-2174.

18. Dolan JP, Diggs BS, Sheppard BC, Hunter JG (2005) Ten-year trend in the national volume of bile duct injuries requiring operative repair. Surg Endosc 19: 967-973.

19. Halilovic H, Hasukic S, Matovic E, Imamovic G (2011) Rate of complications and conversions after laparoscopic and open cholecystectomy. Med Arh 65(6): 336-338.
20. Grbas H, Kunisek L, Zelić M, Petrosić N, Cepić nI, et al. (2013) Outcome evaluation of 10,317 laparoscopic cholecystectomies: a 17-year experience at a single center. Hepatogastroenterology 60(128): 18731876.

21. Fry DE, Pine M, Locke DGP (2015) Composite Measurement of Outcomes in Medicare Inpatient Laparoscopic Cholecystectomy. J Am Coll Surg 221(1): 102-109.

22. Cox MR, Gunn IF, Eastman MC, Hunt RF, Heinz AW (1992) Open cholecystectomy: a control group for comparison with laparoscopic cholecystectomy. Aust N Z J Surg 62(10): 795-801.

23. Roslyn JJ, Binns GS, Hughes EF, Saunders-Kirkwood K, Zinner MJ, et al. (1933) Open Cholecystectomy. A Contemporary Analysis of 42,474 Patients. Ann Surg 218(2): 129-137.

24. Girard RM, Morin M (1993) Open cholecystectomy: its morbidity and mortality as a reference standard. Can J Surg 36(1): 75-80.

25. Cagir B, Rangraj M, Maffuci L, Ostrander LE, Herz BL (1994) A retrospective analysis of laparoscopic and open cholecystectomies. J Laparoendosc Surg 4(2):89-100.

26. Moreaux J (1994) Prospective study of open cholecystectomy for calculous biliary disease. Br J Surg 81(1): 116-119.

\section{Your next submission with Juniper Publishers will reach you the below assets}

- Quality Editorial service

- Swift Peer Review

- Reprints availability

- E-prints Service

- Manuscript Podcast for convenient understanding

- Global attainment for your research

- Manuscript accessibility in different formats

( Pdf, E-pub, Full Text, Audio)

- Unceasing customer service

Track the below URL for one-step submission https://juniperpublishers.com/online-submission.php 